\title{
The relationship between plasma osmolality and plasma vasopressin concentration is altered in old male Lewis rats
}

Citation for published version (APA):

Terwel, D., \& Jolles, J. (1994). The relationship between plasma osmolality and plasma vasopressin concentration is altered in old male Lewis rats. European Journal of Endocrinology, 131(1), 86-90. https://doi.org/10.1530/eje.0.1310086

Document status and date:

Published: 01/01/1994

DOI:

10.1530/eje.0.1310086

Document Version:

Publisher's PDF, also known as Version of record

\section{Please check the document version of this publication:}

- A submitted manuscript is the version of the article upon submission and before peer-review. There can be important differences between the submitted version and the official published version of record. People interested in the research are advised to contact the author for the final version of the publication, or visit the DOI to the publisher's website.

- The final author version and the galley proof are versions of the publication after peer review.

- The final published version features the final layout of the paper including the volume, issue and page numbers.

Link to publication

\footnotetext{
General rights rights.

- You may freely distribute the URL identifying the publication in the public portal. please follow below link for the End User Agreement:

www.umlib.nl/taverne-license

Take down policy

If you believe that this document breaches copyright please contact us at:

repository@maastrichtuniversity.nl

providing details and we will investigate your claim.
}

Copyright and moral rights for the publications made accessible in the public portal are retained by the authors and/or other copyright owners and it is a condition of accessing publications that users recognise and abide by the legal requirements associated with these

- Users may download and print one copy of any publication from the public portal for the purpose of private study or research.

- You may not further distribute the material or use it for any profit-making activity or commercial gain

If the publication is distributed under the terms of Article $25 \mathrm{fa}$ of the Dutch Copyright Act, indicated by the "Taverne" license above, 


\title{
The relationship between plasma osmolality and plasma vasopressin concentration is altered in old male Lewis rats
}

Dirk Terwel and Jellemer Jolles

Duparmen of Newropsychologe and Psychobiolong. Unimarsity of Limburg. The Netherlands

Terwel D. Jolles J. The relationship between plasma osmolality and plasma vasopressin concentration is altered in old male Lewis rats. Eur I Endocrinol 1994:131:86-90. ISSN 0804-4643

\begin{abstract}
Kidney dysfunction has been obserwed in aged humans and rats, the primary cause of which may reside in the kidney itself or in the hypothalamus. "The latter possibility is suggested by the increased release of AVP in response to salt infusion in humans. The effect of age on the relationship between plasma osmolality and plasma AVP concentration has never been verified in an animal model. Therefore, in the present study. $9 \%$ salt solution was infused into adult and aged lewis rats, and plasma AVP concentration and osmolality were measured. Basal plasma AVP concentration, osmolality and total water intake were not altered in aged Lewis rats as compared with adult animals, indicating the absence of overt disturbances in water homeostasis. Infusion of $9 \%$ salt solution resulted in a linexr increase in plasma osmolality in both adult and aged rats. Plasma asmolality increased more with time in aged animals than in adult animals, suggesting an age-related difference in kidney function during salt infusion. Plasma AVP concentration increased $50 \%$ less with osmolality at relatively low osmolalties, but not at relatively high osmolalities. The altered rolationship between plasma osmolality and plasma. AVP concentration in rats with age may be related to changes in neurons monitoring osmolality or to changes in baroreflex regulation. The data suggest that reduced kichey function with age does not result from an altered relationship between plasma osmolality and plasma AVP concentration.
\end{abstract}

D Terwel. University of Limburg. Department of Neuropsychology and Psychobiology, PO Box 616.6200 MD Maastricht. The Netherlands

Aging in rats is accompanied by changes in the control of water homeostasis. The precise nature of these changes at least to some extent appears to be strain-dependent (see Aravich and Sladek (1) for a review). For instance, overt kidney dysfunction is already apparent in Long-Evans rats at 7 months of age (2), whereas the reduced renal concentrating ability in Fischer 344 rats is only observed at 24 months of age $(3,4)$. In several strains of rats the concentration of AVP in plasma has been observed to increase with age [Long-Bvans (5). Wistar (6.7), Brown-Norway [Terwel, unpublished observation)]. In Fischer 344 rats, however, no change in plasma AVP concentration has been observed with age (8). An inability to release sufficient AVP has been observed in Fischer 344 rats during water deprivation (9). This reduced release of AVP could reflect a decreased response of the hypothalamo-neurohypophyseal system (HNS) or insufficient synthesis of AVP. A number of disturbances in the control of water homeostasis have also been observed in humans. These include a decreased thirst sensation (10). reduced renal concentrating ability $(11-14)$ and an increased response of the HNS to an osmotic stimulus $(15,16)$. It may be argued that the increased
AVP release is a response to the water losing state that is present in aging rats with resultant decrease in blood volume and consequent stimulation of the neurohypophyseal system.

However, several findings have been made that suggest that hypervasopressinemiat may downregulate the number of renal VP receptors and be the cause rather than the effect of a renal deficit (2. 5). For instance, it was found that AVP release during in vitro perfusion of hypothalamoneurohypophyseal blocks obtained from 7-month-old Long-Evans rats is increased compared to those from 2-month-old rats (2). Furthermore, the abovementioned observation of an age-associated increase in the response of the HNS to salt loading in humans also favors such a notion. Surprisingly, the response of the HNS to salt loading in relation to age has never been investigated in rats. Since an altered response of the HNS may be an important determinant of changes in the control of water homeostasis in rats with age (see Miller (5), and Aravich and Sladek (1) for a discussion), in the present study the effects of salt infusion on plasma AVP concentration and plasma osmolality were determined in adult and aged Lewis rats. 


\section{Materials and methods}

\section{Animals}

In the present study, male Lewis rats (LEW/CrIBR) of 12 and 28 months of age were used. The rats were bred and kept in our own lacilities and had liree access to lood and water. The temperature of the animal house was approximately $21^{\circ} \mathrm{C}$ and the humidity was $55 \%$. Lights were on from 09.00 to 21.00 . The $50 \%$ survival age of this rat strain is $28-30$ months. Therefore the 28 -month-old rats used can be considered senescent.

For the determination of basal AVP concentration. plasma osmolality and water intake rats were treated as described previously (6). Each age group consisted of 15 animals. Two other groups of 6 animals each were anesthetized with Nembutal ${ }^{\mathbb{B}}(60 \mathrm{mg} / \mathrm{kg}$ pentobarbital, $0.1 \mathrm{ml} / 100 \mathrm{~g}$ body weight), and polyethylene cannulas (ID) $0.28 \mathrm{~mm}$, OD $0.61 \mathrm{~mm}$ ) were inserted into the femoral artery and the contralateral femoral vein. Cannulas were exteriorized and secured at the back of the neck. The animals were allowed to recover from surgery for $24 \mathrm{~h}$, during which time cannulas were flushed twice with $0.25 \mathrm{ml}$ heparin solution. The indwelling cannulas were extended with polyethylene tubing ( $\mathrm{L} 0.5 \mathrm{~m}$. ID $0.75 \mathrm{~mm}$, OD $1.45 \mathrm{~mm}$ ) for infusion of salt solution through the femoral vein and blood sampling through the femoral artery. A blood sample of $1 \mathrm{ml}$ was withdrawn by means of a syringe, and then $9 \%$ salt solution was infused at a rate of $30 \mu \mathrm{l} / \mathrm{min}$. Every $10 \mathrm{~min}$ a $1 \mathrm{ml}$ blood sample was taken. Blood samples were immediately centrifuged. Plasma was replaced with donor plasma and blood cells were resuspended. Blood samples were heated to $37^{\circ} \mathrm{C}$ and returned to the animals between samplings. Plasma samples were stored at $-20^{\circ} \mathrm{C}$ until determination of plasma AVP concentration or kept on ice until determination of plasma osmolality within $2 \mathbf{h}$.

\section{Radioimmunoassay of AVP}

AVP was extracted from plasma samples using heatactivated Vycor ${ }^{\circledR}$ glass powder (Corning Glass Works, New York) as described previously $(6,17)$, except that $250 \mu \mathrm{l}$ plasma samples from salt infused rats were used instead of $1 \mathrm{ml}$ samples and that $50 \mu \mathrm{l}$ of a suspension of $20 \mathrm{mg} / \mathrm{ml}$ glass powder was used instead of $100 \mu \mathrm{l}$. Radioimmunoassay of AVP was also carried out as described previously $(6,17)$. The radioimmunoassay was internally standardized. Internal standards were prepared from portions of AVP-free plasma, to which known amounts of AVP (Sigma, St Louis, USA) had been added. AVP-free plasma was obtained by pre-extraction with Vycor ${ }^{\text {it }}$ glass powder. Displacement of tracer by extracted internal standards versus the amounts of AVP added to the portions of plasma served as an internal standard curve. The intra- and interassay coefficients of wariation were $7.1 \%$ and $8.6 \%$, respectively. Non-specific binding was less than $3 \%$, and binding of tracer by excess antibody was more than $90 \%$. The detection limit was $0.2 \mathrm{pmol} / \mathrm{l}$.

\section{Osmometry}

Osmolality was determined in triplicate by freezingpoint depression in $50 \mu \mathrm{l}$ freshly prepared plasma samples as described by Bohnen et al, (18), using a cryoscopic osmometer (Osmostat 030; Gonotec, Berlin. Germany). The intra-assay coefficient of variation of median values of samples measured in triplicate was $0.18 \%$. The interassay coefficient of variation of median values of the standard measured in triplicate was $0.31 \%$.

\section{Statistics}

When appropriate, Student's t-test was used for comparison of groups of data. The relationship between osmolality and time was evaluated by use of a one lactor analysis of variance with age as between-subject factor and sampling time as repeated measures within-subject factor. Data on plasma osmolality and plasma AVP concentration were fitted to a linear and exponential equation for individual rats. To determine whether the fitted parameters were different between adult and aged rats Student's $t$-test was used. Differences were considered significant when $p<0.05$.

\section{Results}

Table 1 gives some parameters rellated to basal water homeostasis in adult and aged male Lewis rats. Aged animals were heavier than adult animals ( $p<0.001)$, but consumed the same amount of water $(\mathrm{p}>0.05)$. Water intake per $100 \mathrm{~g}$ body weight was reduced in aged rats as compared with adult rats $(\mathrm{p}<0.001)$. Plasma osmolality and plasma AVP concentration were unaltered with age $(p>0.05)$. In contrast, a significant correlation was found between plasma osmolality and plasma $A V P$ concentration in adult animals (plasma AVP] $=0.210$ (plasma osmolality - 293.8), $\mathrm{r}^{2}=0.553, \mathrm{p}<0.01$ ). but not in aged animals $\left(r^{2}=0.013, p>0.05\right)$

As shown in Fig. 1, infusion of $9 \%$ salt solution markedly increased plasma osmolality in Lewis rats. Analysis of variance revealed an effect of age on plasmat osinolality. Plasma osmolality increase was significantly higher in 28-month-old rats than in 12 -month-old rats from the 20 min time point onwards. Vig. $2 A$ shows the relationship between plasma osmolality and plasma AVP concentration for individual adult rats. Data were fitted to a linear $(Y=a(X-b))$ and a transformed exponential ( $\mathrm{In} Y=\mathrm{aX}-\mathrm{b}$ ) equation. There were no differences in the goodness-of-fit for data from adult animals in these two models ir values were 
Table 1. Parameters retated lo wather metabolism in aduh and aged Lewis rats. Values represent means t sam. Wach age group consisted of 15 animals.

\begin{tabular}{lcccc}
\hline $\begin{array}{l}\text { Age } \\
\text { (months) }\end{array}$ & Rat weight & $\begin{array}{c}\text { Total water } \\
\text { intake } \\
\text { (ml/24h) }\end{array}$ & $\begin{array}{c}\text { Water intake } \\
\text { (ml/24h/100g } \\
\text { body weight) }\end{array}$ & $\begin{array}{c}\text { Plasma } \\
\text { osmolality } \\
\text { (mosm/kg) }\end{array}$ \\
\hline 12 & $480 \pm 1.5$ & $25.0 \pm 0.5$ & $5.2 \pm 0.1$ & $301.9 \pm 1.1$ \\
28 & $612 \pm 18^{\text {in }}$ & $25.1 \pm 1.3$ & $4.1 \pm 0.2^{*}$ & $304.1 \pm 1.0$ \\
\hline
\end{tabular}

Significantly different walues are indicated by asterisks ( $p<0.001)$.

$0.955 \pm 0.014$ and $0.942 \pm 0.015$ for the linear and exponential model, respectively: $\mathrm{p}>0.05$ ). Parameters $a$ and $b$ for the linear equation were $3.78 \pm 0.43$ and $300.8 \pm 2.0$ and for the exponential equation $0.149 \pm 0.011$ and $43.5 \pm 3.5$, respectively. Fig. $2 \mathrm{~B}$ shows the relationship between plasma osmolality and plasma AVP concentration in individual aged rats. For aged rats the fit of the data to the exponential equation was superior to the lit to the linear equation ( $r$ values were $0.881 \pm 0.024$ and $0.976 \pm 0.017$ in the linear and exponential model, respectively; $p<0.05$ ). Parameters $a$ and $b$ of the exponential equation were $0.105 \pm 0.017$ and $30.6 \pm 5.3$ for aged rats. Parameter a was significantly different between adult and aged rats $(\mathrm{p}<0.05)$. Parameter b just failed to be significantly alfected by age $(p=0.070)$. Inspection of the data showed that at relatively low osmolalities the increase in plasma AVP concentration with plasma osmolality was lower in aged rats than in adult rats. When the lower halves of the curves (points up to halfway the osmolality rise for each individual rat) were compared according to the linear model, a significant difference was found between the slopes of the curves (slopes were $2.12 \pm 0.21$ and $1.13 \pm 0.14$ for adult and aged rats, $p<0.01$; thresholds were $298.1 \pm 1.7$ and $299.2 \pm$

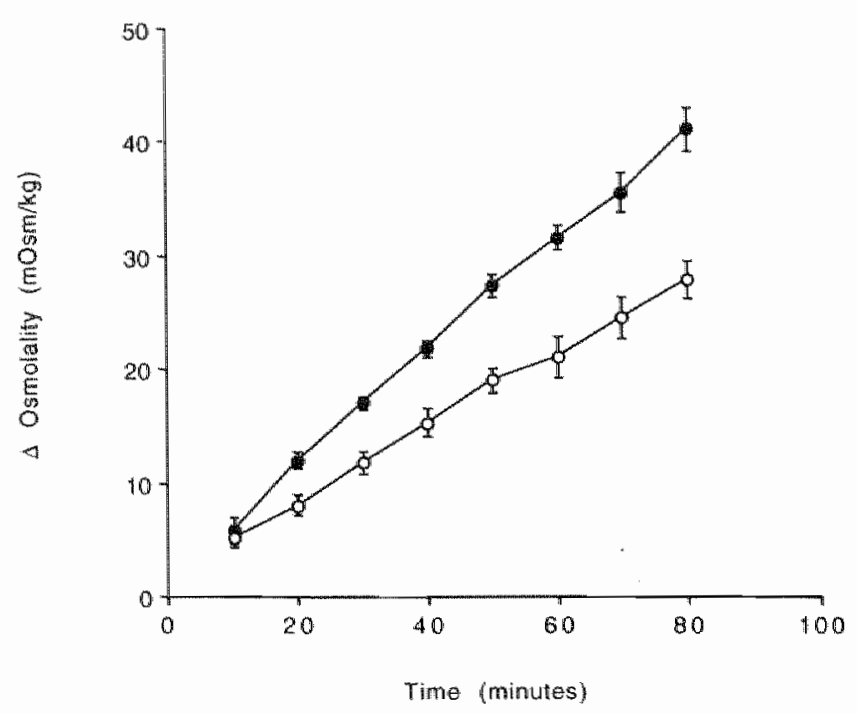

I"ig. 1. Change in plasma osmolabity in adult (o) and aged (-) Lewis rats during infusion of $9 \%$ salt solution. Data represent means tw sEa. Each age group consisted of six animals.
1.2. $\mathrm{p}>0.05$ ). When the lower halves of the curves were compared according to the exponential model, significant differences were observed between parameters $a$ and $b$ for adult and aged rats ( $a$ was $0.263 \pm 0.032$ and $0.127 \pm 0.013$, and $b$ was $78.3 \pm 10.0$ and $35.7 \pm 1.9$, p values $<0.01$ ). Significant differences were not observed when the higher halves of the curves were compared according to either model $(\mathrm{p}$ values $>0.05$ ).

\section{Discussion}

There is some debate as to whether the relationship between plasma osmolality and plasma AVP concentration is linear or exponential. Robertson (19) stated that the assays now available are not sufficiently precise to distinguish clearly between the relatively small differences in plasma AVP concentration predicted by the two models. Indeed, data for adult rats showed equally good fits to the linear and exponential equations. However, data for aged rats fitted the exponential equation best. This may be because higher osmolalities were reached in aged animals or because the curves for aged rats have a different shape. The data do not distinguish between these two possibilities.

The relationship between plasma osmolality and plasma AVP concentration under basal conditions was quite different from that under conditions of salt infusion. The rise in plasma AVP concentration with osmolality was about 10 times higher in the latter case. This observation is of considerable importance for the interpretation of siudies on the physiology of AVP release. As far as we know from the literature. this is the first direct comparison of the relationship between plasma osmolality and AVP concentration under conditions of slowly and rapidly changing osmolality.

In contrast to earlier findings in Wistar rats (6), basal plasma AVP concentration did not increase with age in Lewis rats (6). Moreover, total water intake was unaltered in aged Lewis rats. Therefore, water homeostasis may be undisturbed under basal conditions in aged Lewis rats. However, unpublished results from our laboratory indicate that aged Lewis rats have a decreased renal concentrating ability under conditions of water deprivation. Twelve-month-old $(\mathrm{N}=8)$ and 28-month-old $(\mathrm{N}=8)$ Lewis rats were kept in 

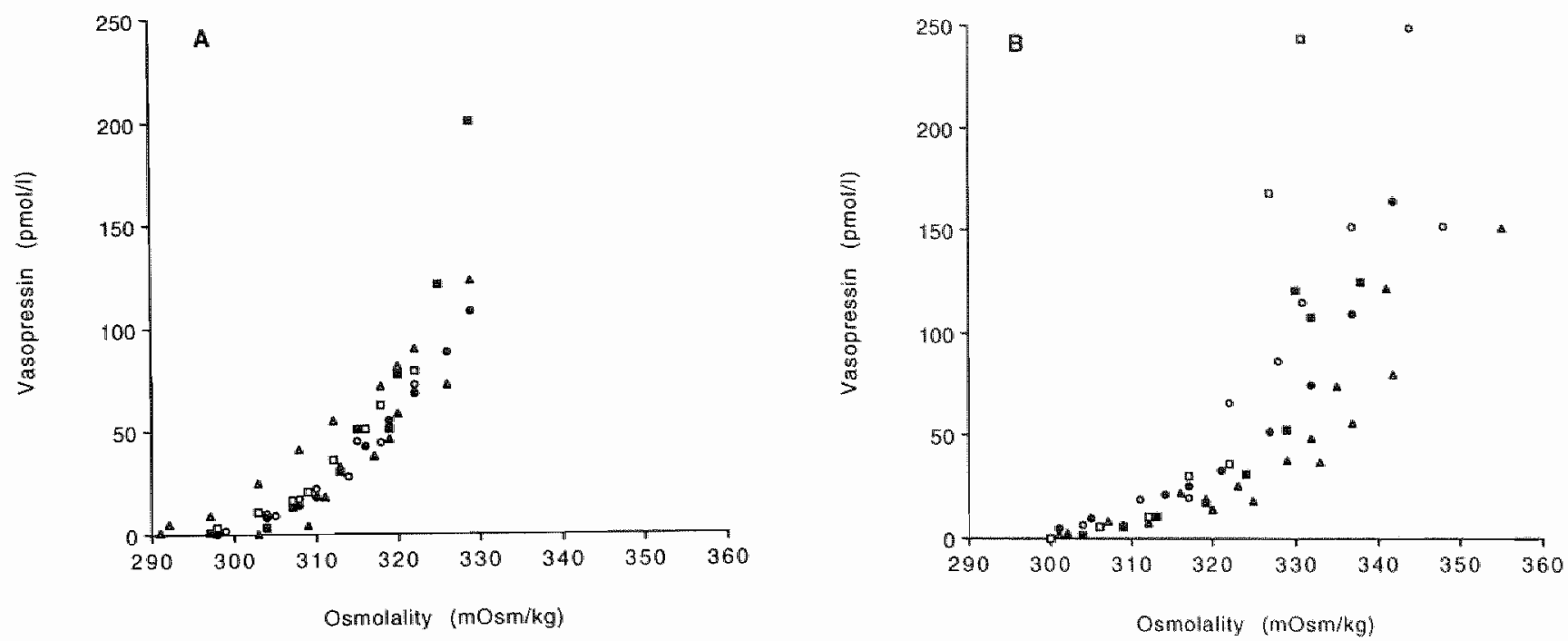

Fig. 2. Relationship between plasma osmolality and plasma vasopressin concentration in adult (A) and aged (B) lewis rats. Symbols indicate individual rats.

metabolic cages. On the fourth day the animals were withheld from water and food. Urine production was $54 \%$ higher in aged rats than in adult rats after $48 \mathrm{~h}$ of water deprivation $(\mathrm{p}<0.01)$ and urine osmolality was $54 \%$ lower after $24 \mathrm{~h}$ and $45 \%$ lower after $48 \mathrm{~h}$ ( $p$ values $<0.001$ ). This is in accordance with the literature, since so far all rat strains examined show changes in water homeostasis that are probably indicative of kidney dysfunction (i.e. increased water intake or urine production), either under basal conditions or under conditions of water deprivation $(2-5,20-22)$.

Salt infusion resulted in a greater increase in osmolality in aged rats than in adult rats. Both adult and aged rats were infused at the same rate, despite the higher body weight of the aged rats. Since aged rats contain more body water, the observed difference in the increase in osmolality may be underestimated. These results resemble those obtained by Cheng and North (23) in a study of Brattleboro and Long-Evans rats. Brattleboro rats showed a larger increase in osmolality during salt infusion than Long-Evans rats. This was explained by the observation that Brattleboro rats have a lower glomerular filtration rate than Long-Evans rats. It is not unreasonable to assume that the same argument could be used to explain the smaller increase in osmolality in adult rats during salt infusion. Alternatively, adult rats may have an increased glomerular filtration rate during salt infusion, whereas aged rats do not, comparable to the occurrence of hyperfiltration in adult rats after a meal and the absence of it in aged rats (24).

For relatively low osmolalities, the increase in plasma AVP concentration with osmolality was greater in adult rats than in aged rats, according to the linear model. One could take issue with the approach of splitting the data. Because the data were split, a correction can be made for post hoc mulliple comparison. When this correction is made the difference between aged and adult rats was still significant.

In contrast to the present observation in rats, in humans the increase in plasma AVP concentration with plasma osmolality is greater in elderly subjects than in adult subjects $(15,16)$. This has been explained by the observation that the barorellex is blunted in aged subjects. Salt infusion increases blood pressure, and the increase in blood pressure suppresses the release of AVP. When the baroreflex is blunted, blood pressure is not adjusted. which results in an increased secretion of AVP. The alternative explanation, that osmoreceptor function is increased in humans, is probably incorrect. Information is conveyed from the osmoreceptors to both the pituitary, to suppress AVP release, and to the cerebral cortex to bring about consciousness of the sensation of thirst. Reduced thirst sensation in humans can be taken to indicate reduced osmoreceptor function (25). However, the difference between humans and rats in the age-related change in the response of the HNS to an osmotic stimulus needs to be explained. As is clear from the above, the release of AVP is governed by mechanisms that counteract each other. In rats, the baroreflex mechanism may be blunted less severely than in humans, whereby a reduced osmoreceptor lunction is revealed.

In conclusion, the response of the HNS to salt loading appears to be reduced rather than increased in aged Lewis rats and is unlikely to contribute to a decreased kidney function. Why this reduced response of the HNS does not result in reduced basal plasma AVP concentrations in Lewis rats is a matter of further investigation. 


\section{References}

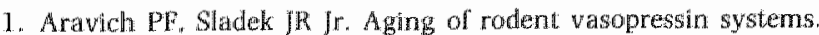
Morphometric and functional considerations. In: Gash PM. Boer GI, eds. Vasopressin. Principles and propertles. New York: Plenum, 1987:497-516

2. Miller M. Increased wasopressin secretion: an early manfestation of aging in the rat. I Gerontol 1987:42:3-7

3. Bengele HH. Mathias $\mathbb{R S}$, Perkins $\mathbb{J H}$. Alexander EA. Urinary concentrating dafect in the agged rat. Am I Physiol 1981; 240:147-50

4. Beck $\mathbb{N}, Y_{u} B P$. Effect of aging on urtnary concentrating mechanism and vasopressin-dependent $\mathrm{CAMP}^{\mathrm{in}}$ rats. Am I Physial $1982: 243: 5121-5$

5. Miller M. Intluence of aging on vasopressin secretion and water regulation. In: Schrier RW ed. Vasopressin. New York: Raven Press, 1985:249-58

6. Terwel D. Ten Haaf IA. Markerink M. Jolles J. Changes in plasma vasopresstr concentration and plasma osmolality in relation to age and time of day in the male Wistar rat. Acta Endocrinol $1992: 126: 357-62$

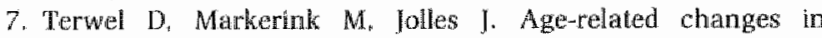
concentrations of vasopressin in the central nervous system and plasma of the male Wistar rat. Mech Ageing Dew $1992: 65: 127-36$

8. Silverman WF, Aravich PA, Sladek JR Jr, Sladek CD. Physiological and biochemical indices of neurohypophyseal function in the aging Fischer rat. Neuroendocrinology 1990:52:18:-90

9. Sladek CD. McNeill TH, Gregg CM, Blair ML, Baggs RB. Vasopressin and renin response to dehydration in aged rats. Neurobiol Aging 1981:2:293-302

10. Phillips PA, Ledingham IGG, Rolls $B$, Crowe MI. Wollner L. Reduced thirst perception after water deprivation in healthy elderly man. N Engl J Med 1984:31 1:753-9

11. Lewis WH Jr. Alving AS. Changes with age in the renal function of adult men. Am J Physiol 1936:123:500-15

12. Miller IH, Shock NW. Age differences in renal tubular response to antidiuretic hormone. J Gerontol 1953:8:466-50

13. Lindeman RRD, Lee TD Jr, Yengst MI, Shock NW. Inlluence of age, renal disease, hypertension. duretics, and calcium on the sntidiuretic responses to suboptimal infusions of vasopressin. Clin Med 1966:68:206-23
14. Rowe JW. Shock NW. DeFronzo RA. The influence of age on the renal response to water deprivation in man. Nephron $1976: 17$ : $270-8$

15. Helderman $\mathbb{I H}$, Vestal RE, Rowe JW, Tobin $\mathbb{D D}$, Andres $\mathbb{R}$, Robertson GL. The response of arginine vasopressin to intrawenous athanol and hypertonic saline in man: the impact of aging. $\int$ Gerontol 1978:33:39-47

16. Bevilacqua M. Norbiato G, Chebat E, Raggi U, Cavaiani P. Guzzetti $R$, et al. Osmotic and non-osmotic control of vasopressin release in the elderly: effect of metoclopramide. I Clin Endocrinol Metab $1987: 65: 1243-7$

17. Ten Haaf $\mathrm{A}$. Terwell D, Van de Heijning HIM. Van Wimersma Greldanus TjB. Radiommunoassay: a goal or a tool' j Control Rel $1992: 21: 23-36$

18. Bohnen N, Terwel D, Markerink M. Ten Haaf JA, Jolles J. Pitfalls in the measurement of plasma osmolality pertinent to research in vasopressin and water metabolism. Clin Chem 1992;38:2278-80

19. Robertson GL. Physiology of ADH secretion. Kidney Int 1987: 32 (Stappl):20-6

20. Corman B, Milchel J-B. Glomerular filtration, renal blood flow, and solute excretion in conscious aging rats. Am I Physiol 1987:253: R555-60

21. Goudsmit E Fliers $\mathbb{W}_{\text {, Swatab }} \mathrm{DF}^{3}$. Vasopressin and oxytocin excretion in the Brown Norway rat in relation to aging. water metabolism and testosterone. Mech Ageing Dev 1988:44: $241-52$

22. Geelen $G_{1}$ Corman B. Rellationship between vasopressin and renal concentrating ability in aging rats. Am If Physiol 262:1992: R $826-33$

23. Cheng SWT. North WG. Responsiveness of oxytocin-producing neurons to acute salt loading in rats: comparisons with vasopressin-producing neurons. Neuroendocrinology 1986:42: $1.74-80$

24. Corman B, Chami-Khazraji S. Schaeberbeke J. Michel JB. Effect of feeding on glomerular filtration rate and proteinuria in conscious rats. Am I Physiol 1988:255:F250-6

25. Phillips PA. Bretherton M, Johnston CI, Gray L. Reduced osmotic thirst in healthy elderly men. Am J Physiol 1991:261:R166-71

Received September $27 \mathrm{th}, 1993$

Accepted March 24th, 1994 